\title{
THE PROPERTIES OF EDIBLE FILM DERIVED FROM BOVINE SPLIT HIDE GELATIN WITH ISOLATED SOY PROTEIN USING VARIOUS LEVELS OF GLYCEROL IN THE PRESENCE OF TRANSGLUTAMINASE
}

\section{SIFAT-SIFAT EDIBLE FILM DARI GELATIN KULIT SAPI SPLIT DAN SOY PROTEIN ISOLAT PADA PENAMBAHAN TRANSGLUTAMINASE DENGAN VARIASI GLISEROL}

\author{
Dwi Wulandari ${ }^{12 *}$, Yuny Erwanto ${ }^{1}$, Yudi Pranoto ${ }^{3}$, and Rusman ${ }^{1}$ \\ ${ }^{1}$ Departement of Animal Products Technology, Faculty of Animal Science, Gadjah Mada University, \\ Yogyakarta, 55281 \\ ${ }^{2}$ Study Program of Leather Processing Technology, Polytechnic ATK, Yogyakarta, 55188 \\ ${ }^{3}$ Faculty of Agricultural Technology, Gadjah Mada University, Yogyakarta, 55281
}

Submitted: 25 April 2017, Accepted: 18 July 2017

\begin{abstract}
This study examined the characteristics of the edible film derived from a combination of bovine split hide gelatin and isolated soy protein, cross-linked using transglutaminase enzyme with various levels of glycerol as a plasticizer. The materials used in this research were bovine split hide gelatin, isolated soy protein, transglutaminase enzyme, and glycerol. Data were analyzed by using completely randomized design, and each treatment was replicated three times, and glycerol levels as a treatment were 10, 20, and $30 \%$. The results showed that the glycerol levels significantly affected by the thickness, elongation, solubility, degree of cross-linking, and water vapor transmission rate (WVTR), but not on the tensile strength. The addition of glycerol made the film more elastic and the surface of the film was more homogeneous and compact. In conclusion, the increase of glycerol level up to $30 \%$ affected on the increase of mechanical properties of the edible film.
\end{abstract}

(Key words: Bovine split hide, Edible film, Gelatin, Isolated soy protein,Transglutaminase enzyme)

\section{INTISARI}

Tujuan penelitian ini untuk mengetahui karakteristik edible film campuran gelatin kulit sapi split dan isolated soy protein (protein kedelai terisolasi), cross-linked menggunakan enzim transglutaminase dengan penambahan level gliserol sebagai plasticizer. Materi yang digunakan adalah gelatin kulit sapi split, isolated soy protein, enzim transglutaminase dan gliserol. Penelitian menggunakan Rancangan Acak Lengkap pola searah dengan level gliserol sebagai perlakuan (10, 20, dan 30\%) dengan ulangan 3 kali. Hasil penelitian menunjukkan perbedaan yang nyata terhadap ketebalan, kemuluran, kelarutan, derajat cross linking dan water vapor transmission rate (WVTR) serta tidak berpengaruh nyata terhadap kekuatan tarik film. Penambahan gliserol menyebabkan film menjadi lebih elastis dan permukaan film lebih homogen dan kompak. Semakin meningkat level gliserol sampai 30\% akan mempengaruhi terhadap peningkatan sifat mekanis edible film.

(Kata kunci: Edible film, Enzim transglutaminase, Gelatin, Kulit sapi split, Protein kedelai terisolasi)

\section{Introduction}

Functional properties of gelatin are necessary for industrial food application such as stabilizers, gelling agent, binding, thickening, emulsifying, edible packaging as well as edible film. For the gelatin application reasoning, their physical and qualitative properties require some improvements, which can be made via enzymatic combination with others proteins (Nomura et al., 2000), protein mixing and enzymatic modification (Erwanto et al., 2005), or structure modification (Alting et al., 2000). The utility of bovine split hide gelatin combine with other protein such as isolated soy protein is a chance to increase the physical

\footnotetext{
${ }^{*}$ Korespondensi (corresponding author):

Telp. +62 81328227403

E-mail: dwiwulandari25@yahoo.com
} 
properties of gelatin products since the skin more useful for the leather products.

Bovine split hide is a by-product from tanning industry that has a relatively high protein content, which is $22.5 \%$ (Wulandari et al., 2016). In another hands, bovine split gelatin is abundant things in Indonesia. According to Suharjito (2007) and Hastutiningrum (2009) that bovine split hide contained collagen protein which when it was hydrolyzed can produce gelatin, then it can make a further product such as edible film.

Edible film is a thin layer of edible and is often used as a coating of food, moisture barrier, oxygen and solute movement in food (Bourtoom, 2008). Advantages of the use of edible films for packaging are to extend the shelf life of the product and do not pollute the environment, because it can be eaten directly with the product that is packed. However, edible films as food packaging have limitations such as water vapor resistance and lower mechanical strength than synthetic polymers. To modify the network polymer and chemical cross-linked, heating or enzymatic cross-linked can occur crosslinking among amino acids in the second functional chain protein (Chambi and Grosso, 2006), then this can improve the quality of edible film properties and simultaneously reduce such limitations.

Research by Cao et al. (2007) made an edible film from a combination of B-type bovine with isolated soy protein with the heating process. Chambi and Grosso (2006) was able to create an edible film of a combination of B-type bovine gelatin with casein through an enzymatic process. The enzyme that was often used as a crosslinked agent among the two proteins was transglutaminase enzyme (TGse, proteinglutamine c-glutamyl transferase, EC 2.3.2.13) catalyzed the reaction of acyl transfer between the $\mathrm{Y}$-glutamine residues carboxiamide group (acyl donor) and the eamino lysine residues (acyl acceptor), resulting in the formation of (e- $\mathrm{Y}$-glutamyl) lysine intra- and intermolecular cross-linked protein (De Jong and Koppelman, 2002). The formation of crosslinking did not reduce the nutritional quality of the food as lysine residues remain available for digestion (Yokohama et al., 2004).

The effect of the TGase treatment on the film properties had been investigated in several proteins such as soy flour (Mariniello et al., 2003), gelatin (Thomazine et al., 2005) and combine bovine gel with exogenous protein using Tgase (Erwanto et al., 2005). Cross-reactions can also be applied to the glutamine and lysine of two different types of proteins, resulting in the formation heteropolymers (De Jong and Koppelman, 2002). Yildirim and Hettiarachchy (1998) used transglutaminase to produce films from isolated whey protein and soy protein. These films showed a high elongation, low tensile strength and no significant effect on water vapor permeability of the film protein. Transglutaminase was efficient in lowering Water vapor permeability (WVP) gelatin films, but there was no change in the tensile strength of the film modification (Carvalho and Grosso, 2004).

The formation of edible films usually used plasticizer as a qualifier plastic material to obtain flexibility of the edible film. The addition of plasticizer in the formation of edible matrix film from fish collagen was reported than it can increase the water vapor permeability and elongation and decrease elasticity but it has limited effect on the tensile strength of the edible film (Shaw et al., 2003). Glycerol was a plasticizer widely used in the manufacture of edible film. The development of edible film by combining animal proteins such as gelatin from the bovine split hide and vegetable proteins such as isolated soy protein, with the addition of transglutaminase enzyme as a cross-linking agent, and with the glycerol as a plasticizer was an innovative research in packaging food and interesting to do. Therefore the objectives of this of this study were to develop an edible film based on mixed bovine split hide gelatin and isolated soy protein, cross-linked using transglutaminase enzyme with the addition of various glycerol level as a plasticizer and to improve the mechanical and morphological properties of the resulting edible film.

\section{Materials and Methods}

Materials of this research were bovine split hide gelatin, isolated soy protein (ISP), transglutaminase enzyme. The tools used in the research were knives, analytical balance, water baths, glass tools, thermometers, oven, Universal Testing Machine, SEM.

\section{Combine gelatin preparation}

Comparison of combination gelatin from bovine split hide and ISP were 90:10, so 
the final solution was $10 \%(w / v)$. Gelatin from bovine split hide and ISP were dissolved by $\mathrm{dH}_{2} \mathrm{O}$ at $55^{\circ} \mathrm{C}$ and stirred for $30 \mathrm{~min}$. It was then added with $\mathrm{NaOH} 0.1 \mathrm{~N}$ to adjusted $\mathrm{pH}$ 7. After that, 30 Units of TGase were

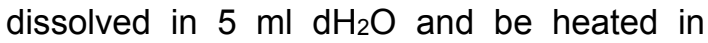
$50^{\circ} \mathrm{C}$ for $15 \mathrm{~min}$ with slowly stirring. To inactive the reaction, the solutions were being heated at $85^{\circ} \mathrm{C}$ for $10 \mathrm{~min}$. Then the filtrates were poured into a tray and dried in an oven at $50^{\circ} \mathrm{C}$ for $36-48 \mathrm{~h}$.

\section{Edible film preparation}

Method to produce the edible film based on Chambi and Grosso (2006), Carvalho and Grosso (2004), Sobral et al. (2001) and Kim (2006). Seven percent of bovine split hide gelatin was dissolved by $\mathrm{H}_{2} \mathrm{O}$ at $55^{\circ} \mathrm{C}$ for $30 \mathrm{~s}$, added by different concentrations of glycerol 10, 20, and $30 \%$ as treatment of T0.10, T0.20 and T0.30 (control). For T1, T1.20 and T1.30 treatments, $7 \%$ combination gelatin was dissolved in distilled water at $55^{\circ} \mathrm{C}$ for $30 \mathrm{~s}$, added $10 \%, 20 \%, 30 \%$ of glycerol. Each filtrates was poured into a tray and dried in an oven at $50^{\circ} \mathrm{C}$ for $48 \mathrm{~h}$ then edible film removed and put it in the exicator. Scheme of making the edible film was shown in Fig 1.

\section{Thickness measurement}

The thickness was measured with a micrometer to the nearest $0.001 \mathrm{~mm}$, by placing the film between the jaw micrometer. The thickness was measured at five different points, for each film sample to be tested, and then calculated their mean.

\section{Tensile strength measurement}

The tensile strength of edible films was tested using Universal Testing Instrument Lloyd's LRX 5K-type machine according to the method of Kim et al. (2002). The tensile strength value was calculated by dividing the maximum load by the initial cross-sectional area of the specimen.

\section{Elongation testing}

Elongation is expressed as the maximum force that is given to the film to tear (Newton) divided by the film crosssectional area $\left(\mathrm{m}^{2}\right)$, while the length is calculated as [( $\Delta$ tmax $\mathrm{x}$ test speed) /length films beginning ] $\times 100 \%$ according to the method of Kim et al. (2002).

\section{Solubility (TSM) analysis}

The amount of dissolved material (TSM) was determined by methods Gontard et al. (1993). Dried specimens from a cast film were placed in $30 \mathrm{ml}$ of distilled water and stored in an environmental chamber at $25^{\circ} \mathrm{C}$ for $24 \mathrm{~h}$ with occasional gentle stirring. The insoluble dry matter was measured by removing the film pieces from the beakers, gently rinsing them with distilled water, and then drying them in an air-circulating oven at $105^{\circ} \mathrm{C}$ for $24 \mathrm{~h}$ (wf). To calculate the required TSM weight of the material beginning before it is dissolved (W1). TSM measured by the equation :

$$
\mathrm{TSM}=(\mathrm{W} 1-\mathrm{Wf}) / \mathrm{W} 1 \times 100
$$

\section{Degree of cross- linking measurement}

Cross-linking degree was measured by the method Abdel-Mohsen et al. (2011). The dry weight of the film was weighed, then the film was immersed in the solvent $\left(\mathrm{dH}_{2} \mathrm{O}\right)$ for 24 hours. After immersion, the film was dried in the oven at $60^{\circ} \mathrm{C}$ until dry. The dry weight of the film after immersion was determined by weighing using the scale. The degree of cross linking was measured by the percentage of comparing the dry weight of the hydrogel films after immersion $(\mathrm{Wg})$ and hydrogel films weight before immersion (W0). $\mathrm{DC} \%=\mathrm{Wg} / \mathrm{W} 0 \times 100 \%$

\section{Water vapor transmission rate test}

Water vapor transmission rate was tested with desiccant Gravimetric Method (ASTM, 1995). Water transmission rate is expressed as the slope of the gain edible film $(\mathrm{g} / \mathrm{h})$ divided by vast areas of the film tested $\left(\mathrm{m}^{2}\right)$.

\section{Film morphology observation}

Analysis of the edible film morphology was observed by Scanning Electron Microscope (SEM) type JEOL JSM-5310 LV at 4000 times magnification for a flat crosssectional area

\section{Experimental design and data analysis}

Data were analyzed using completely randomized design, each treatment was replicated three times, and glycerol as a treatment levels $(10,20$, and $30 \%)$. Mean differences were tested by Duncan's multiple range test according to Steel and Torrie (1993). 


\section{Results and Discussion}

\section{Thickness}

The thickness of edible film was shown in Table 1. This results showed that glycerol concentration significantly affected $(P<0.05)$ on the thickness of the edible film, but not affected on control of the edible film. The higher concentration of glycerol tended to increase the thickness of an edible film. According to Tapia-Blacido et al. (2005), the concentration of dissolved solid affected on the thickness of the edible film. Zhang and Han (2006) stated that the increase of thickness of the edible film caused by increase of plasticizer.

The thickness of an edible film in this research was about $0.093-0.224 \mathrm{~mm}$. This result were lower than the thickness of the edible film that was combined between chicken leg gelatin and isolated soy protein, that was $0.124-1.83 \mathrm{~mm}$ (Hasdar, 2011). The different of amino acid structure, intramolecular distribution, triple helix formation, and proteins hydrophobic differentiation are the main factors in the formation of an edible film (Perez et al., 2007).

\section{Tensile strength}

Results of the statistical analysis showed that increasing of glycerol concentration level did not affect the tensile strength of the edible film, but it significantly affected $(P<0.05)$ on control of the edible film. Increasing the concentration level of glycerol caused decreasing of a tensile strength of the edible film. According to Genadios et al. (1998), glycerol plasticizer had hydrolphilic properties, hydrophilic properties caused binding properties emerged for the formation of a cavity that could disrupt attractive force of intramolecular. The edible film was more flexible caused the force required to pull the edible film got smaller so that its strength was low.

The tensile strength of the edible film in this research ranged from 1.032 to 2.011 $\mathrm{MPa}$. It was still in the range of other research such as Hasdar (2011), which was from 1.50 to $2.70 \mathrm{MPa}$. Its tensile strength was lower than gelatin from pig skin, which was 2.820-5.637 MPa (Sompie, 2014) and lower than gelatin from goat skin which was 1.714 - $5.770 \mathrm{MPa}$ (Said, 2011). It was caused by isolated soy protein as a raw material of the edible film. Cho and Rhee (2004) stated that all of the component of isolated soy protein was not contributed in the formation of the film.

Based on the results, a tensile strength of samples was higher than control. It was caused by the treatment of TGase enzyme that acted as cross-linking agents. Crosslinking of peptide made molecule chain and molecule weight higher, so the tensile strength became higher too.

\section{Elongation}

Based on statistical analysis, Table 1 showed that increasing concentration level of glycerol (30\%) has significantly effect $(P<0.05)$ on the elongation of edible film, but not affect the control of the edible film. Plasticizer glycerol had a textural effect that can increase the flexibility of the protein matrix so that the elongation of the edible film increased too (Reed et al., 1998). Rodriques et al. (2006) reported that one of the factors that influence the edible film elongation was the addition of glycerol as plasticizer. Glycerol had relatively small molecules with the hydrophobic properties, so it is easily fit into the chains of proteins and created hydrogen

Table 1. Average of physical and chemical properties of edible films with different concentrations of glycerol

\begin{tabular}{|c|c|c|c|c|c|c|}
\hline \multirow[t]{2}{*}{ Parameter } & \multicolumn{3}{|c|}{$\begin{array}{c}\text { Bovine split hide gelatin (BSHG/control } \\
\text { Glycerol Concentration (\%) }\end{array}$} & \multicolumn{3}{|c|}{$\begin{array}{c}\text { BSHG + ISP +TG ase Glycerol } \\
\text { Concentration(\%) }\end{array}$} \\
\hline & 10 & 20 & 30 & 10 & 20 & 30 \\
\hline Thickness (mm) & $0.082 \pm 0.01$ & $0.079 \pm 0.01$ & $0.089 \pm 0.01$ & $0.111 \pm 0.02^{a}$ & $0.139 \pm 0.04^{b}$ & $0.151 \pm 0.03^{b}$ \\
\hline $\begin{array}{l}\text { Tensile strength } \\
\text { (Mpa) }\end{array}$ & $1.789 \pm 0.62^{y}$ & $0.788 \pm 0.13^{x}$ & $0.726 \pm 0.06^{x}$ & $1.593 \pm 0.51$ & 1. $39, \pm 0.08$ & $1.221 \pm 0.10$ \\
\hline Elongation (\%) & $41.26 \pm 7.68$ & $53.94 \pm 11.97$ & $55.93 \pm 5.93$ & $56.35 \pm 11.66^{a}$ & $67.50 \pm 4.25^{\mathrm{a}}$ & $77.64 \pm 9.20^{\mathrm{b}}$ \\
\hline Solubility (\%) & $87.39 \pm 2.09 y$ & $84.34 \pm 3.15^{y}$ & $46.23 \pm 1.63^{x}$ & $74.87 \pm 5.42^{b}$ & $28.48 \pm 2.36^{a}$ & $24.63 \pm 3.21^{\mathrm{a}}$ \\
\hline $\begin{array}{l}\text { Degree of Cross } \\
\text { Linking }(\%)\end{array}$ & $68.37 \pm 6.22$ & $69.05 \pm 5.69$ & $75.76 \pm 1.23$ & $72.52 \pm 3.62^{\mathrm{a}}$ & $76.93 \pm 0.83^{a}$ & $78.81 \pm 1.20^{\mathrm{b}}$ \\
\hline $\begin{array}{l}\text { WVTR (g.H2O. m - } \\
\left.\text { 2.j.jam }{ }^{-1}\right)\end{array}$ & $10.59 \pm 1.21^{x}$ & $17.44 \pm 1.71^{y}$ & $19.08 \pm 1.95^{y}$ & $8.95 \pm 0.30^{a}$ & $12.27 \pm 1.04^{b}$ & $17.35 \pm 1.28^{c}$ \\
\hline
\end{tabular}


bonding in the edible film with the amide group and amino acid side chains of proteins (Gontard et al., 1993).

The elongation of samples in this research ranged from 42.934 to $88.119 \%$. This was almost similar to the results Said (2011) which were 54.051 to $95.117 \%$ of the goat skin gelatin elongation and higher than Hasdar research (2011), which was from 19.7 to $49.4 \%$ of the elongation of combined gelatin from chicken legs skin and isolated soy protein. A higher value was influenced by the used of $30 \%$ glycerol resulting in more flexible films and the addition of transglutaminase enzyme that acts as a cross-linking agent who formed crosslinks across protein molecules.

\section{Solubility}

Table 1 showed that increasing of glycerol levels significantly affected $(P<0.05)$ on the solubility of the edible film at the level of $30 \%$ as well to control of the edible film. Decreasing solubility due to increased levels of glycerol. The addition of plasticizer in the solution of the edible film caused an increase in the intermolecular and intramolecular bonds. The intermolecular bonds including the disulfide S-S (Mendieta-Taboada et al., 2007). Increased concentration of plasticizer will give the effect to narrow intermolecular space, consequently, will affect to the decrease of edible film solubility.

The average of the solubility of samples in this research was $44.66 \%$. This result closed to the results of research of HeTang et al. (2005), which used isolated soy protein with TGase enzyme treatment. The solubility of that samples decreased significantly after the treatment using TGase, this was due to the occurrence of crosslinked by TGase so that the molecular weight of the protein increased causing descend solubility of the edible film.

\section{The degree of cross-linking}

Cross-linking is a bond linking one polymer with other polymers can form covalent and non-covalent interactions and may improve hydrogel polymer molecules (Hennik and Nostrum, 2002). Statistical analysis in Table 1 showed that the increase levels of glycerol had significantly effect $(P<0.05)$ on the degree of cross-linking edible film at the level of $30 \%$ but had no effect on the control films. Increasing the degree of crosslinking caused by increased levels of glycerol. The Plasticizer is an agent that helps the formation of a flexible film, there by improving the mechanical properties of the film. The hydrophilic component was a molecule which was relatively small and can easily fit among the protein chains and form hydrogen bonds among the amide groups on the protein gluten (Gontard et al., 1993). The increasing degree of isolated soy protein indicates that the crosslinked film of the gelatin hydrogel was not dissolved in the solvent, resulting in a more intact physical appearance than the low isolated soy protein degree with the physical appearance of the film destroyed.

The addition of glycerol level will increase the intermolecular cross-linked of the protein because glycerol was a polysaccharide with a molecular weight of certain water-soluble. These compounds will be absorbed intensively to form hydrogen bonds with water (Nieto, 2009). Yi et al. (2006) reported that the increase in the degree of isolated soy protein of gelatin films of fish caused by increased transglutaminase enzyme treatment, from $6.80 \%$ to $32.59 \%$. The enzymatic cross-linked could cause an increase in molecular weight fish gelatin (Gomez-Guillen et al., 2001).

\section{Water vapor transmission rate (WVTR)}

One of the functions of an edible film was the ability to hold water vapor (Gontard et al., 1993). Statistical analysis showed that increase levels of glycerol significantly affected $(P<0.05)$ on the water vapor transmission rate (WVTR) of edible film. Increased levels of plasticizer caused more moisture from the air was absorbed so that the WVTR value and flexibility of edible film increased (Navaro-Tarazaga et al., 2008).

The average of WVTR of the edible film increased due to increase levels of glycerol. This was due to the hygroscopic properties of glycerol. Glycerol was an alcohol tri hidrico which was colorless and odorless, hygroscopic and can absorb water from the air (Anonimous, 2004). The higher level of glycerol caused more moisture was absorbed from the air so that WVTR increased.

WVTR of in this research resulted in range from 8.64 to $18.69 \mathrm{~g} . \mathrm{H}_{2} \mathrm{O} . \mathrm{m}^{-2} \mathrm{~h}^{-1}$. This value was higher than the gelatin from goatskin (Said, 2011) which was 0.387 to 
1.73 g. $\mathrm{H}_{2} \mathrm{O} \cdot \mathrm{m}^{-2} \mathrm{~h}^{-1}$ and gelatin from pig skin (Sompie, 2014), i.e., 5.827 to $8.878 \mathrm{~g} . \mathrm{H}_{2} \mathrm{O}$. $\mathrm{m}^{-2} \mathrm{~h}^{-1}$. The differences were due to the treatment transglutaminase which acted as a cross-linked agent. According to the results of research He-Tang et al. (2005), that the WVTR of isolated soy protein based films increased after being treated transglutaminase i.e., from 1.24 to $36.51 \mathrm{~g}$. $\mathrm{H}_{2} \mathrm{O}$. $\mathrm{m}^{-2} \mathrm{~h}^{-1}$. Chambi and Grosso (2006) stated that the value WVP films increased due to the enzyme treatment. This increase was due to increasing mobility, the lengthening of the protein chain and

Bovine split hide gelatin (T0)/combinations gelatin (T1) 7\% (w/v)

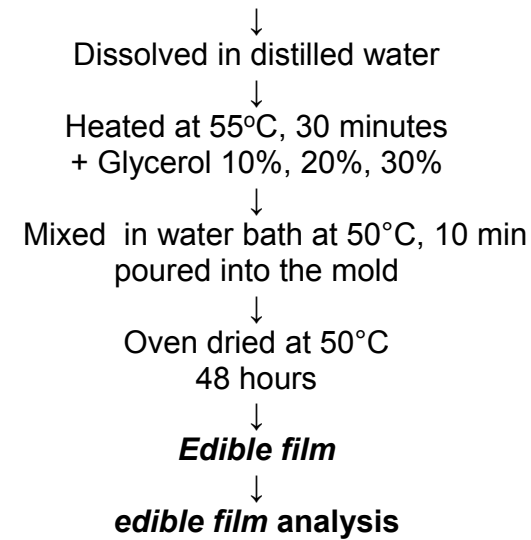

Tensile strength, elongation, thickness, SEM

Solubility, water vapor transmission rate, degrees cross link

Figure 1. Flowchart of making edible film to treatment T0 and T1
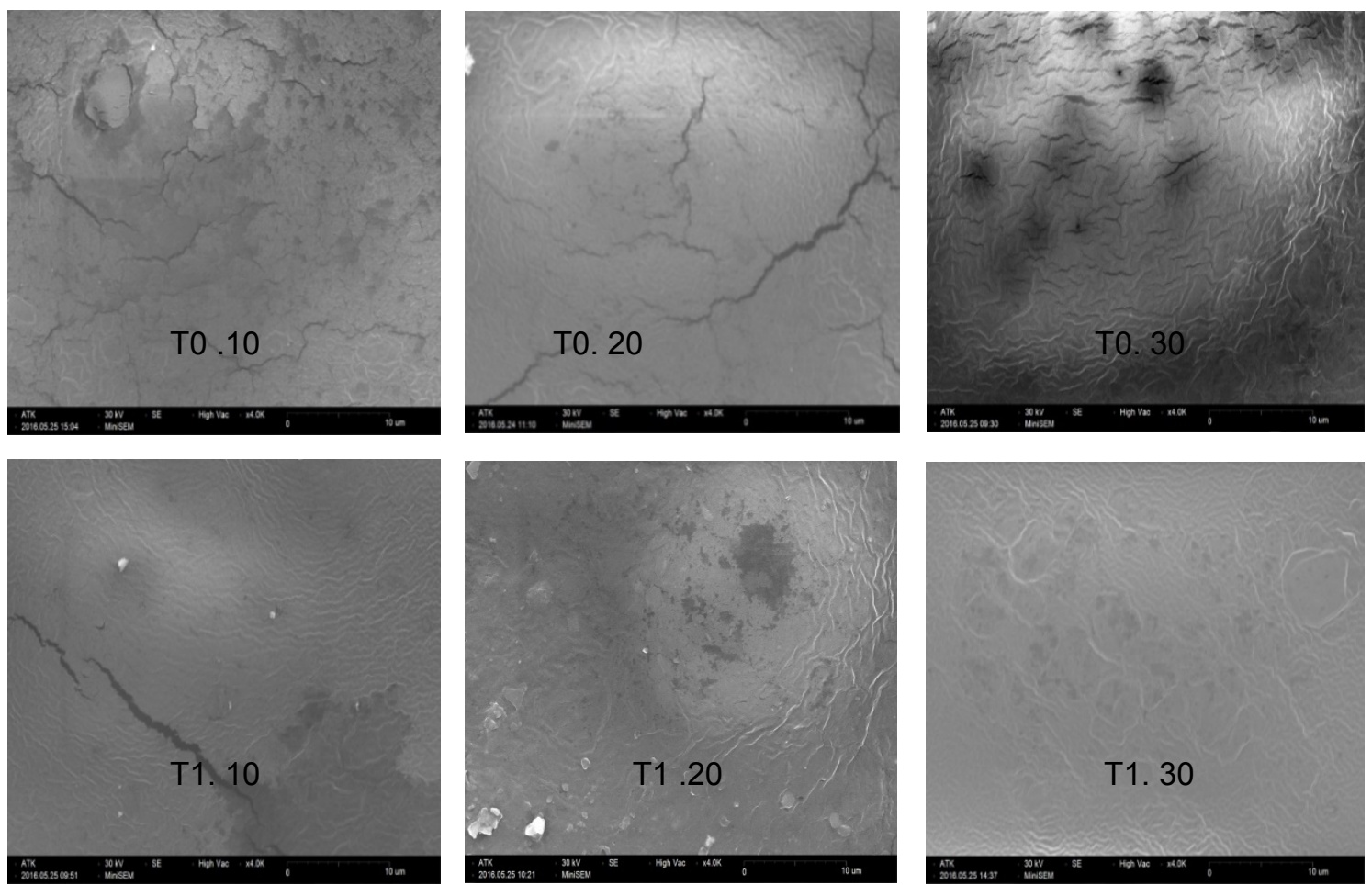

Figure 2. The results of scanning electron micrograph of edible film from bovine split hide gelatin and isolated soy protein with a cross-linked enzyme transglutaminase using glycerol.

T0. $10=$ Bovine split hide gelatin with $10 \%$ glycerol, T0. $20=$ Bovine split hide gelatin with $20 \%$ glycerol, T0. $30=$ Bovine split hide gelatin with $30 \%$ glycerol, T1. $10=$ Bovine split hide + isolated soy protein + Enzim TG ase + glycerol 10\%, T1. 20 = Bovine split hide+ isolated soy protein + Enzim TG ase + glycerol $20 \%$, T1. $30=$ Bovine split hide + isolated soy protein + Enzim TG ase + glycerol $30 \%$. 
increasing the diffusion of water. Crosslinked could increase the number of hydrophobic amino acids on the surface of the film (Chen, 2002), while Orliac et al. (2002) observed that increase of in film surface hydrophobicity resulted in increase of water resistance of the film.

\section{Edible film morphology}

Morphology of edible film could be described using scanning electron micrograph (SEM). SEM analysis results of the edible film (Figure 2) showed that the higher increase levels of glycerol, lead to the smaller and more compact the pores of edible film and cracks of the edible film. This phenomena is a result that the higher levels of glycerol caused lower tensile strength and higher elongation (Sompie, 2014). Glycerol as a plasticizer entered among collagen fibrils and protein bonds, so the distance between protein chains to be longer, the film would be easily moved, not easily broken, and the fragile properties of the film were reduced (Chambi and Grosso, 2006).

Figure 2 showed that the structure of edible film T0 had much cracks on the surface than edible film T1. The combination of gelatin and isolated soy protein with a combination of $90: 10$ and the addition of transglutaminase occurred good homogenization process ( $\mathrm{TI})$. Reduction of such cracks showed that the edible film T1 had good physical structure. Good structure of edible film had the structure of collagen fibrils that blend with isolated soy protein particles through a heating process. This was in accordance with the opinion of Chambi and Grosso (2006), that the alternatives to improve the function of protein on edible film were through a heating process, chemically or enzymatically so that can occurr a crosslinked the chain of amino acids on the chain functional of proteins.

The difference of physical structure between T0 and T1 was due to the interaction between bovine split hide gelatin, isolated soy protein, and the cross-linked transglutaminase. These results were consistent with research Mariniello et al. (2003) that the film from soy flour and pectin by treatment with transglutaminase has a smoother surface, more compact and higher homogeneity than the untreated transglutaminase.

\section{Conclusion}

Treatment of glycerol levels on the characteristics of bovine split hide gelatin and isolated soy protein with the addition of transglutaminase enzyme significantly affected by the thickness, elongation, solubility, degree of cross-linking and WVTR, but did not significantly affected on the tensile strength of the film. The addition of glycerol caused the film became more elastic, and the film surface is more homogeneous and compact. Increase levels of glycerol to $30 \%$ affected the mechanical properties of an edible film.

\section{References}

Abdel-Mohzen, A. M., A. S. Aly, R. Hrdina, A. S. Montaser, and A. Hebeish. 2011. Eco-Synthesis of PVA/chitosan hydrogels of biomedical aplication. J. Polym. Environ. 19: 1005-1012.

Alting, A. C., R. J. Hamer, C. G. De Kraif and R. W. Visschers. 2000. Formation of disulfide bonds in acid induced gels of preheated whey protein isolate. J. Agric. Food Chem. 48: 5001-5007.

Anonimous. 2004. Glycerol, Related : Organic Chemistry. http://www. Encyclopedia.com. Accessed on Juny 13, 2014.

ASTM. 1995. Standard test method for water vapor transmission of materials E 9695. In: Annuals Book of ASTM Standards. R. A. Storer (ed.). PA: American Society for Testing and Materials, Philadelphia. pp. 697-704.

Bourtoom. 2008. Edible film and coatings characteristics and properties. Int. J. Food Resour. 15: 1-9.

Cao, N., Y. Fu and J. He. 2007. Preparation and physical of isolated soy protein and gelatin composite films. J. Food Hydrocolloids. 21: 1153-1162.

Carvalho, R. A. and C. R. F. Grosso. 2004. Characterization of gelatin based films modified with transglutaminase, glyoxal and formaldehyde. Food Hydrocolloids. 18: 717-726.

Chambi, H. and C. Grosso. 2006. Edible film produced with gelatin and casein cross-linked with transglutaminase. Int. J. Food Res. 39: 458-466.

Chen, H. 2002. Formation and properties of casein films and coatings. In: Protein- 
Based Films and Coatings. A. Gennadios (Ed.). FL: CRC Press, Boca Raton. pp. 181-211.

Cho, S. Y. and C. Rhee. 2004. Sorption characteristics of soy protein film and the irrelation to mechanica properties. Lebensmittle -Wissenschaft undTechnology. 35: 151-157.

De Jong, G. A. H. and S. J. Koppelman. 2002. Transglutaminase catalyzed reactions: impact on food applications. J. Food Sci. 67: 2798-2806.

Erwanto, Y., S. Kawahara, K. Katayama, A. L. M. Ahmed, K. Yamauchi, K. B. Chin, and M. Muguruma. 2005. Effect of existence of exogenous protein on physicochemical properties of heatand transglutaminase-induced bovine collagen-peptide gel. J. Food Sci. 70: E.505-509.

Gennadios, A., J. M. Rhim, A. Handa, C. L. Weller, and M. A. Hanna. 1998. Ultraviolet radiation affects physical and molecular properties of soy protein films. J. Food Sci. 63: 559-563.

Gomez-Guillen, M. C., A. I. Sarabia, M. T. Solas, and P. Montero. 2001. Effect of microbial transglutaminase on the functional properties of megrim (Lepidorhombus boscii) skin gelatin. J. Sci. Food Agric. 81: 665-673.

Gontard, N, S. Guilbert, and J. L. Cuq. 1993. Water and glyserol as plasticizer afect mechanical and water barrier properties of an edible wheat gluten film. J. Food Sci. 58: 206-211.

Hasdar. 2011. Characterization of edible film produced from a combination of chicken legs skin gelatin and isolated soy proteins. Thesis Faculty of Animal Husbandry of Gadjah Mada University, Yogyakarta.

Hastutiningrum, S. 2009. Utilization waste split leather tanning industry to glue the hydrolysis of collagen. J. Technol. 2: 208-212.

Hennik, W. E. and C. F. van Nostrum. 2002. Novel crosslinking methods to design hydrogels. Advanced dry delivery. Reviews. 15: 13-36.

He-Tang, C., Y. Jiang, Q. B. Web and X. Q. Yang. 2005. Effect of transglutaminase treatment on the properties of cast film of isolated soy proteins. J. Biotechnol. 120: 296-307.

Kim, K. W., C. J. Ko, and H. J. Park. 2002. Mechanial properties, water vapor permeabilities and solubilities of highly carboxymethylated starch-based edible films. J. Food Sci. 67: 218-222.

Kim, Y. T. 2006. Development and Characterization of Gelatin Film Asa Active Packaging Layer. Clemson University, Clemson.

Mariniello, L., P. Di Pierro, C. Esposito, A. Sorrentino, P. Masi, and R. Porta. 2003. Preparation and mechanical properties of edible pectin-soy flour films obtained in the absence or presence of transglutaminase. J. Biotechnol. 102: 191-198.

Mendieta-Taboada, O., P. Jose do, A. Sobral, R. A. Carvalho, A. Monica, and B. Q. Habitante. 2007. Thermomecanichal properties of biodegradable films based on blends of gelatin and poly (vinyl alcohol). Food Hydrocolloids. 22: 1458-1492.

Navarro-Taragaza, M. L., R. Sothornvit, and M. B. Perez-Gago. 2008. Effect of plasticizer tyoe and amount on hydroxypropyl methylcellulosebeeswax edible film properties and postharvest quality of coated plums (Cv. Angeleno). ASAP. J. Agr Food Chem. 32: 223-228.

Nieto, M. B. 2009. Structure and Function of Polysaccharide Gum-Based Edible Films and Coatings for Food Applications, Ed. Me embuscado and kc Huber. 57-112. Springer, New York.

Nomura, Y, S. Toki, Y. Ishii and K. Shirai. 2000. Improvement of material propety of shark type I collagen by composing with pig type I collagen. J. Agric. Food Chem. 48: 6332-6336.

Orliac, O., A. Roully, F. Silvestre, and L. Rigal. 2002. Effects of additives on the mechanical properties, hydrophobicity and water uptake of thermo-moulded films produced from sun flower protein isolate. Polymer. 43: 5417-5425.

Perez, M, P. Montero, and M. C. Gomez. 2007. Formulation and stability of biodegradable film made from cod gelatin and sun fower oil blends. Food Hidrocolloids. 1-31.

Reed, T., A. H. Barret, J. Briggs, and M. Richardson. 1998. Texture and storage stability of processed beef sticks as affected by glycerol and moisture levels. J. Food Sci. 63: 84-87. 
Rodriquez, M., J. Ose's, K. Ziani, and J. I. Mate. 2006. Combined effect of plasticizers and surfactans on the physical properties of starch based edible film. Food Res. Int. 39: 840-846.

Said, M. I. 2011. Optimization of the production process goat skin gelatin edible film as a raw material for drug packaging material (capsule). Dissertation. Graduate Program Faculty of Animal Husbandry, Gadjah Mada University, Yogyakarta.

Shaw, N. B., A. O. Sullivan, K. Hoffmann, and J. P. Kerry. 2003. Edible film from fish collagen - the effect of species and fishing grounds on their physical properties.

http://www.rf.15/taft2003/Poster/20abst racts/shawcollagen.pdf. Accessed on Oktober 8, 2013.

Sobral, P. A. J., F. C. Menegalli, M. D. Hubinger and M. A. Roques. 2001. Mechanical water vapor barrier and thermal properties of gelatin based edible film. Food Hidrocolloids. 15: 423-432.

Sompie, M. 2014. Characterization of edible films made basic pig skin gelatin as pork packers. Dissertation. Post graduate program Faculty of Animal Husbandry, Gadjah Mada University, Yogyakarta.

Steel, R. G. and J. H. Torrie. 1993. Principle and Procedure of Statistic. Mc. Graw Hill Book Compani, Inc New York.

Suharjito. 2007. Potential and prospects of industrial gelatin from bovine split hide. Journal of Sci Tech Plan. 5: 43-48.
Tapia-Blacido, D., P. J. Sobral, and F. C. Menegalli. 2005. Development and characterization of biofilms base on amaranth flour (Amaranthus caudatus). J. Food Engineering. 67: 215-223.

Thomazine, M., R. A. Carvalho, and P. J. A. Sobral. 2005. Physical properties of gelatin films plasticized by blends of glycerol and sorbitol. J. Food Sci. 70: 172-176.

Wulandari, D., S. Triatmojo, Y. Erwanto and Y. Pranoto. 2016. Physicochemical properties and amino acid and fuctional group profiles of gelatin ectracted from bovine split hide cured by acid. Pakistan J. Nut. 15: 655-661.

Yi, J. B., Y. T. Kim, H. J. Bae, W. S. Whiteside, and H. J. Park. 2006. Influenche of transglutaminaseinduced cross-linking on properties of fish gelatin film. J. Food Eng. Phy. Prop. 71: 376-383.

Yildirim, M. and N. S. Hettiarachchy. 1998. Properties of films produced by crosslinking whey proteins and $11 \mathrm{~S}$ globulin using transglutaminase. J. Food Sci. 63: 248-252.

Yokoyama, K., N. Nio, and Y. Kikuchi. 2004. Properties and applications of microbial transglutaminase. Appl. Microbiol. Biot. 64: 447-454.

Zhang, Y. and J. H. Han. 2006. Plasticization of pea starch film with monosacharides and polyols. J. Food Sci. 71: 253-261. 